\title{
Mapping of a New hem Gene in Escherichia coli K12
}

\author{
By A. SĂSĂRMAN, P. CHARTRAND,* M. LAVOIE, D. TARDIF, \\ R. PROSCHEK AND C. LAPOINTE \\ Department of Microbiology and Immunology, University of Montreal, Montreal, \\ Quebec, Canada
}

(Received 12 December 1978)

\begin{abstract}
A new type of haem-deficient mutant was isolated in Escherichia coli $\mathrm{K} 12$ by neomycin selection. The mutant, designated SASX38, accumulated uroporphyrin, coproporphyrin and protoporphyrin. Since it possessed normal ferrochelatase activity, it was assumed to be deficient in protoporphyrinogen oxidase activity. The gene affected in the mutant was designated hemG. Mapping of the hem $G$ gene by phage Pl-mediated transduction showed that it was located very close to the chlB gene (frequency of cotransduction $78.7 \%$ ), between the met $E$ and rha markers. This location is distinct from the other known hem loci in $E$. coli $\mathrm{K} 12$.
\end{abstract}

\section{INTRODUCTION}

The conversion of COPROGEN III to PROTO IX is carried out by two enzymes, the COPROGEN III oxidase and the PROTOGEN IX oxidase (Jackson et al., 1974; Jacobs \& Jacobs, 1975; Porra \& Falk, 1964; Poulson \& Polglase, 1974, 1975; Sano \& Granick, 1961; see also Fig. 1). The first is responsible for the conversion of COPROGEN III to PROTOGEN IX, and the second for the oxidation of PROTOGEN IX to PROTO IX. PROTOGEN IX oxidase activity has been detected in yeast (Poulson \& Polglase, 1974, 1975) and mammalian mitochondria (Poulson, 1976) and in bacteria (Jacobs \& Jacobs, 1975, 1976; Poulson et al., 1976). The enzyme was isolated recently from yeast (Poulson \& Polglase, 1975) and mammalian mitochondria (Poulson, 1976). However, no mutants deficient in PROTOGEN IX oxidase activity have been isolated so far.

Haem-deficient mutants have been studied most thoroughly in bacteria. Most of the hem genes have already been identified in Escherichia coli K12 (Chartrand et al., 1979; Powell et al., 1973; Săsărman et al., 1975; Săsărman et al., 1968a,b), in Salmonella typhimurium (Săsărman \& Desrochers, 1976; Săsărman et al., 1970), in Bacillus subtilis (Berek et al., 1975) and in Staphylococcus aureus (Tien \& White, 1968). In an attempt to map the gene of PROTOGEN IX oxidase, a collection of unidentified haem-deficient mutants of $E$. coli $\mathrm{K} 12$ were examined. The mutants were selected by neomycin as previously described (Săsărman et al., 1970). One of the unidentified haem-deficient mutants was affected in a gene distinct from the other known hem genes, The results of the biochemical and genetic studies of this new haem-deficient mutant of E. coli $\mathrm{K} 12$ are presented here.

\section{METHODS}

Abbreviations. PBG, Porphobilinogen; URO, uroporphyrin; COPRO, coproporphyrin; COPROGEN, coproporphyrinogen; PROTO, protoporphyrin; PROTOGEN, protoporphyrinogen.

Bacterial strains and bacteriophage. The derivatives of $E$. coli $\mathrm{K} 12$ are listed in Table 1 . The bacteriophage P1kc was obtained from Professor P. Fredericq (University of Liege, Belgium).

* Present address: Institute of Virology, University of Glasgow, Glasgow G11 5JR, Scotland. 


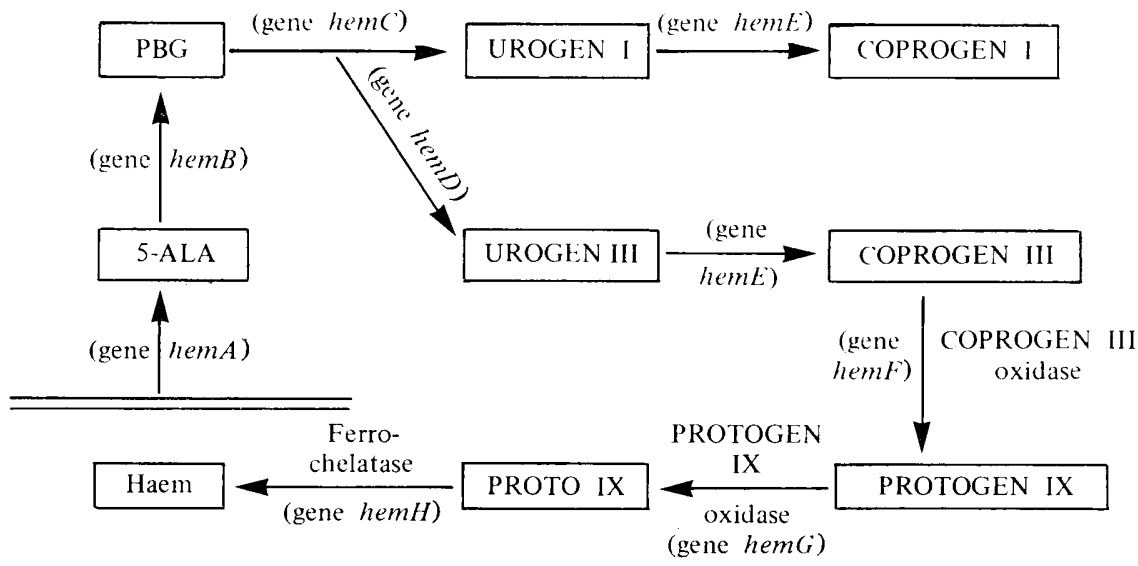

Fig. 1. Biosynthesis of haem: enzymes of the late steps of biosynthesis and proposed nomenclature of hem genes of E. coli K12 (Jackson et al., 1974; Jacobs \& Jacobs, 1975; Lascelles, 1964; Porra \& Falk, 1964; Poulson \& Polglase, 1974; Poulson \& Polglase, 1975; Sano \& Granick, 1961; Săsărman \& Desrochers, 1976; Tait, 1968). Abbreviations: 5-ALA, 5-aminolaevulinic acid; PBG, porphobilinogen; UROGEN, uroporphyrinogen; COPROGEN, coproporphyrinogen; PROTOGEN, protoporphyrinogen; PROTO, protoporphyrin.

Table 1. Derivatives of $E$. coli $\mathrm{K} 12$ used

\begin{tabular}{|c|c|c|}
\hline Strain & Genotype* & Source \\
\hline SASX38 & hem $G 38$ mutation in $\mathrm{Hfr}$ Cavalli & This laboratory \\
\hline Hfr Cavalli & met $B 1$, rel- $1 ; \mathrm{Hfr}$ & W. Hayes \\
\hline AB1931 & $\begin{array}{l}\operatorname{argH1}, \text { metE46, purFl, xyl-7, rel-1(?), } \\
\text { sup-16, sup-48(?); Hfr }\end{array}$ & E. Adelberg \\
\hline AT753 & $\begin{array}{l}\operatorname{argH1}, \text { ilv-1, metB1, thi-1, gal-6, lac } Y 1, \\
\text { or lacZ4, rha-1, str-8, supE44(?), } \lambda^{-} ; \mathrm{F}^{-}\end{array}$ & A. L. Taylor \\
\hline SAS229 & $\begin{array}{l}\text { ilvD75, leu-6, metE46, pro-36, thr-1, trp-42, } \\
\text { gal-6, lac Y1, mtl-2, str-9 }\end{array}$ & This laboratory \\
\hline SAS246 & $\begin{array}{l}\operatorname{argH1}, \text { his-1, metE46, thr-1, thi-1, purE43, } \\
\text { gal-6, lac } Y 1, \text { xyl-7, chlB2, str-121 }\end{array}$ & This laboratory \\
\hline $442-\mathrm{F}$ & $\begin{array}{l}\arg H 1, \text { his- } 1, \text { leu- } 6, \text { pro-33, thr- } 1, \text { thi- } 1, \\
\text { purE43, ara-13, gal-6, lac } Y 1, \text { malAl, mtl-2, } \\
\text { xyl-7, chlB2, str-121, ton }-2, \lambda^{\mathrm{r}}, \lambda^{-} ; \mathrm{F}^{-}\end{array}$ & $\begin{array}{l}\text { B. Bachmann (CGSC); } \\
\text { originally described } \\
\text { by F. Casse }\end{array}$ \\
\hline
\end{tabular}

* For definitions of gene symbols, see Bachmann et al. (1976).

Media. Bacteria were grown in brain heart infusion (BHI, Difco) or on brain heart infusion agar ( $1 \cdot 5$ to $2 \%, \mathrm{w} / \mathrm{v}$; Difco). The synthetic medium was Simmons agar base (Difco), supplemented with the required growth factors and $0.4 \%(\mathrm{w} / \mathrm{v})$ glucose.

Chemicals. Organic solvents for the extraction and identification of porphyrins were reagent or USP grade. Peroxides were removed from diethyl ether as desribed by Perrin et al. (1966). Porphyrin methyl esters and porphyrin precursors were obtained from Sigma and were Sigma grade. Free porphyrins were obtained by hydrolysis of the corresponding methyl esters as described by Falk (1964). Biuret reagent was obtained from Hycel, Houston, Tex., U.S.A., and the human protein standard was obtained from Dade, Miami, Fla., U.S.A. Neomycin sulphate was obtained from Sigma.

Selection of haem-deficient mutants. These were selected by neomycin as described previously (Săsărman et al., 1970).

Extraction and identification of porphyrins in bacterial cultures. Two different types of cultures were used for the extraction of porphyrins: (i) bacteria grown for $72 \mathrm{~h}$ at $37^{\circ} \mathrm{C}$ on $2 \% \mathrm{BHI}$ agar in Roux bottles; (ii) bacteria grown aerobically overnight in $\mathrm{BHI}$ at $29^{\circ} \mathrm{C}$. At the end of the incubation period, bacteria were harvested from the first type of culture by washing the agar with saline and then centrifuging. The supernatant and the bacterial pellet were extracted separately. Porphyrins were extracted by the ether-cyclohexanone method (Dresel et al., 1956; Kennedy, 1956), as adapted for bacteria (Săsărman et al., 1975). 
Table 2. Accumulation of porphyrins in cultures of SASX38

\begin{tabular}{|c|c|c|c|c|c|}
\hline \multirow[b]{2}{*}{$\begin{array}{l}\text { Growth } \\
\text { medium }\end{array}$} & \multirow[b]{2}{*}{$\begin{array}{l}\text { Incubation } \\
\text { conditions }\end{array}$} & \multirow[b]{2}{*}{$\begin{array}{c}\text { Preparation } \\
\text { extracted }\end{array}$} & \multicolumn{3}{|c|}{ Porphyrins [nmol $\left.(\mathrm{g} \text { dry } \mathrm{wt})^{-1}\right]^{*}$} \\
\hline & & & URO & COPRO & PROTO \\
\hline BHI agar & $37^{\circ} \mathrm{C}, 72 \mathrm{~h}$ & Intact cells & 554 & 1011 & trace \\
\hline BHI & $29^{\circ} \mathrm{C}, 14 \mathrm{~h}$ & $\begin{array}{l}\text { Supernatant of } \\
\text { ultrasonically } \\
\text { disrupted cells }\end{array}$ & 972 & 256 & 74 \\
\hline
\end{tabular}

\footnotetext{
* The amount of porphyrins extracted from the supernatant of ultrasonically disrupted cells was normalized to $500 \mathrm{mg}$ protein $\mathrm{ml}^{-1}$.
}

From the second type of culture, bacteria were harvested by centrifugation and then disrupted in an ultrasonic cell disintegrator (model Biosonik III; Bronwill Scientific, Rochester, N.Y., U.S.A.). The preparation was then centrifuged for $40 \mathrm{~min}$ at $14000 \mathrm{~g}$ in the cold. Porphyrins were extracted from the supernatant by ethyl acetate/acetic acid (3:1, v/v) (Falk, 1964; Sano \& Granick, 1961) followed by cyclohexanone, the latter step being identical in both methods.

The yield of porphyrins was calculated using the molar absorption coefficients for free porphyrins, with the corrections recommended by Rimington (1960) and Porra \& Falk (1964).

Porphyrin synthesis in bacterial extracts. The cell-free supernatant prepared from disrupted bacteria (see above) was used immediately or stored at $-20^{\circ} \mathrm{C}$. The protein content of the bacterial extracts was determined by the biuret method (Layne, 1957); it varied from 20 to $35 \mathrm{mg} \mathrm{ml}^{-1}$. For the determination of in vitro porphyrin synthesis, PBG was used as a precursor. The reaction mixture contained $1.0 \mathrm{ml}$ extract in $0 \cdot 1$ M-Tris/HCl buffer ( $\mathrm{pH} \mathrm{8.2),} \mathrm{3.3} \mathrm{mM-EDTA} \mathrm{and} 500 \mathrm{nmol}$ PBG, and was incubated aerobically for $4 \mathrm{~h}$ in the dark at $29^{\circ} \mathrm{C}$. Porphyrins were extracted by the ether-cyclohexanone method as previously described (Săsărman et al., 1975).

COPROGEN III oxidase activity in bacterial extracts. COPROGEN III was prepared by reducing COPRO III with sodium amalgam (Sano \& Granick, 1961). COPROGEN III oxidase activity in bacterial extracts was determined by a modification of the method of Sano \& Granick (1961). The reaction mixture contained 1.4 ml extract in $0.1 \mathrm{M}$-Tris/ $\mathrm{HCl}$ buffer (pH 7.2), $0.9 \%(\mathrm{w} / \mathrm{v}) \mathrm{KCl}, 20 \mathrm{~mm}-\mathrm{EDTA}$ and $100 \mathrm{nmol}$ COPROGEN III, and was incubated aerobically for $1 \mathrm{~h}$ at $38^{\circ} \mathrm{C}$ in the dark. Porphyrins were extracted and identified as described by Sano \& Granick (1961).

Ferrochelatase activity in bacterial extracts. Ferrochelatase activity was determined as described by Porra \& Jones (1963). The reaction mixture contained $1.0 \mathrm{ml}$ extract, $200 \mathrm{nmol}$ potassium phosphate buffer ( $\mathrm{pH}$ $7 \cdot 8$ ), $30 \mathrm{nmol}$ reduced glutathione, $1 \%(\mathrm{v} / \mathrm{v})$ Tween $80,400 \mathrm{nmol} \mathrm{FeSO}$ and $200 \mathrm{nmol}$ PROTO IX, in a final volume of $4.2 \mathrm{ml}$. It was incubated anaerobically at $37^{\circ} \mathrm{C}$ for $2 \mathrm{~h}$. Haem was determined at the end of the incubation period as described by Porra \& Jones (1963).

Assay of catalase activity. Catalase activity was determined as described by Herbert \& Pinsent (1948).

Mapping of the hemG gene. This was done by phage P1-mediated transduction (Lennox, 1955). The phage lysate was irradiated by an optimal dose of ultraviolet light (Wilson, 1960) in order to increase the low frequency of transduction obtained with haem-deficient recipients.

\section{RESULTS}

\section{Biochemical study of the mutant}

Strain SASX38 is a spontaneous haem-deficient derivative of E. coli $\mathrm{K} 12 \mathrm{Hfr}$ Cavalli, selected by neomycin. Its growth on normal media is slow and results in the formation of dwarf colonies. After several days of incubation, the colonies acquire a red fluorescence in ultraviolet light $(365 \mathrm{~nm})$, due to the accumulation of porphyrins.

The extraction and identification of the porphyrins accumulated by SASX38 showed the presence of only URO and COPRO in bacteria incubated for $72 \mathrm{~h}$ (Table 2). However, when porphyrins were determined in extracts of $14 \mathrm{~h}$ cultures, PROTO was also found, in addition to URO and COPRO. Under the same conditions, the parental strain Hfr Cavalli did not accumulate porphyrins (results not shown). The absence of PROTO from the extracts of bacteria incubated for $72 \mathrm{~h}$ (Table 2) may be due to the conversion of PROTO to haem, rather than to its inactivation (see Discussion). 
Table 3. Enzyme activities in extracts of E. coli $\mathrm{K} 12 \mathrm{Hfr}$ Cavalli and SASX38

Net synthesis of tetrapyrroles (nmol)

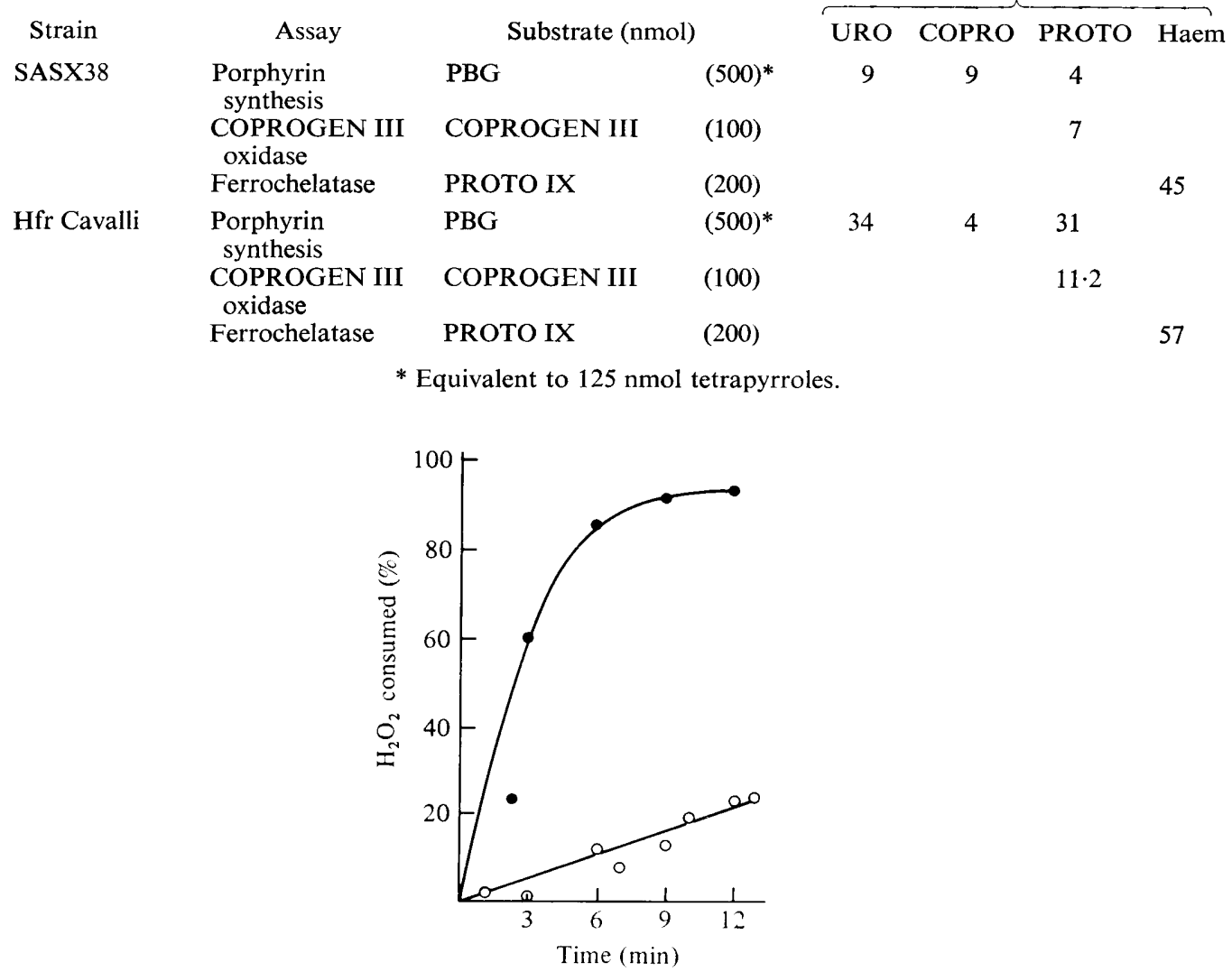

Fig. 2. Catalase activity of E. coli K12 strains: $\bigcirc$, SASX38;, Hfr Cavalli.

Porphyrin synthesis in extracts of SASX38 was less efficient than in extracts of the parental strain (Table 3). Thus the accumulation of porphyrins cannot be due to a derepression of the early hem genes.

COPROGEN III oxidase and ferrochelatase activities in extracts of SASX38 were similar to the corresponding activities of the parental strain. Hence, the accumulation of porphyrins cannot be attributed to a deficiency of the ferrochelatase.

The catalase activity of SASX38 was very low compared with that of the parental strain (Fig. 2). In spite of the normal ferrochelatase activity of the mutant (Table 3), very little haem was synthesized.

\section{Mapping of the hem $G$ gene}

The results of the transduction experiments (Table 4) show that hem $G$ is located very close to $c h l B$ (frequency of cotransduction $78.7 \%$ ), between the metE and rha markers (Fig. 3). This location corresponds to $85 \mathrm{~min}$ on the chromosomal map of E. coli K12 (Bachmann et al., 1976). Analysis of classes of transductants did not allow the deduction of the relative order of the hem $G$ and $c h l B$ genes. 
Table 4. Results of transduction experiments by phage Plkc

\begin{tabular}{|c|c|c|c|c|c|c|}
\hline \multirow[b]{2}{*}{ Donor } & \multirow[b]{2}{*}{ Recipient } & \multirow{2}{*}{$\begin{array}{c}\text { Selected } \\
\text { marker }\end{array}$} & \multirow{2}{*}{$\begin{array}{l}\text { No. of } \\
\text { transductants } \\
\text { analysed }\end{array}$} & \multicolumn{3}{|c|}{ Donor alleles in transductants $(\%)$} \\
\hline & & & & metE & $\operatorname{chlB}$ & rha \\
\hline SAS246 & SASX38 & hemG $G^{+}$ & 399 & $13 \cdot 5$ & $78 \cdot 7$ & \\
\hline AT753 & SASX38 & hem $G^{+}$ & 197 & & & $1 \cdot 5$ \\
\hline $442-\mathrm{F}$ & AB1931 & $m e t E^{+}$ & 197 & 100 & $15 \cdot 0$ & \\
\hline 442-F & SAS229 & $m e t E^{+}$ & 193 & 100 & $10 \cdot 4$ & \\
\hline
\end{tabular}

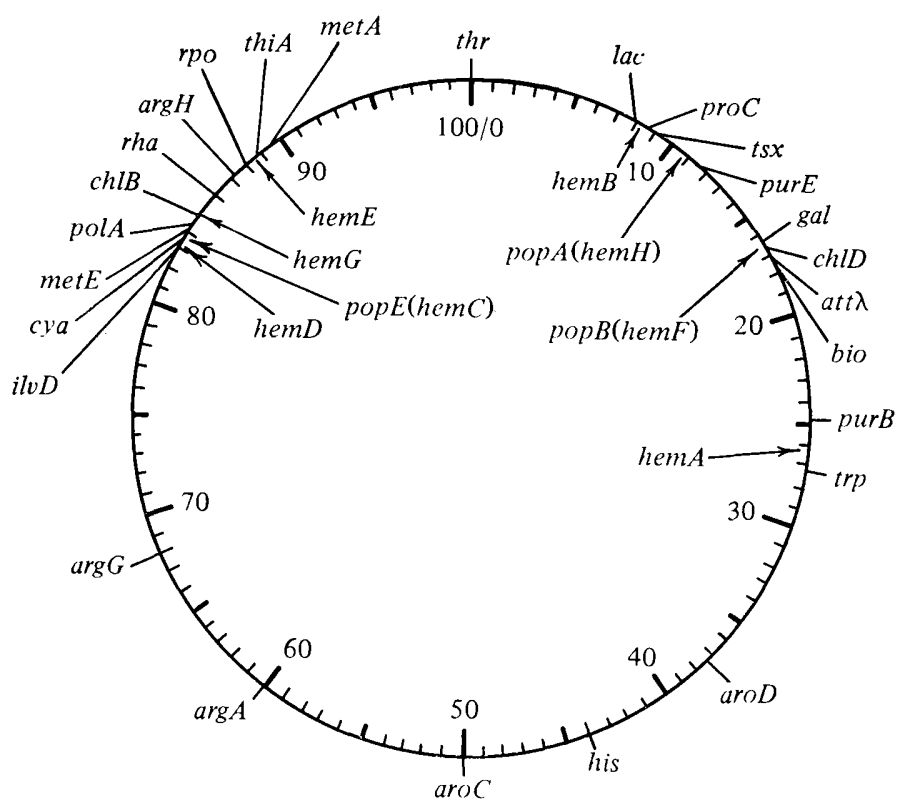

Fig. 3. Location of hem genes on the chromosomal map of E. coli K12 (Bachmann et al., 1976; Chartrand et al., 1979; Cox \& Charles, 1973; Powell et al., 1973; Săsărman et al., 1975; Săsărman et al., 1968a; Săsărman et al., 1968b); designations proposed for pop genes are in parentheses.

\section{DISCUSSION}

$\mathrm{Hem}^{+}$strains do not accumulate porphyrins under normal growth conditions due to a very efficient regulatory mechanism, involving haem as the main effector (Lascelles, 1975). However, porphyrins accumulate in bacteria when the synthesis of haem is deficient. Only the intermediates which precede the mutation accumulate and hence the pattern of accumulation reflects the site of mutation.

The extraction of porphyrins from strain SASX38 showed that it accumulates URO, COPRO and PROTO. This may be due to mutations in two different genes. The better known of the two is the gene of ferrochelatase which is responsible for the insertion of iron into the molecule of PROTO IX to give protohaem. The corresponding gene has already been mapped in E. coli K12 (Cox \& Charles, 1973; Powell et al., 1973), and its location is different from that found in strain SASX38. Moreover, the ferrochelatase activity of SASX38 is normal which indicates that the accumulation of porphyrins cannot be due to a deficiency of this enzyme. The second gene whose mutation could also lead to the accumulation of PROTO is that of PROTOGEN IX oxidase. This enzyme is responsible for the oxidation of PROTOGEN IX to PROTO IX, and it was isolated only recently (Poulson \& Polglase, 1975). PROTOGEN IX oxidase activity has been detected directly in extracts of $E$. coli by Jacobs \& Jacobs $(1975,1976)$. Unfortunately, their technique cannot be applied to mutant 
SASX38 due to the presence of large amounts of porphyrins in the extracts (Table 2). However, indirect evidence strongly supports the assumption that the mutant is deficient in PROTOGEN IX oxidase activity. Indeed, the accumulation of PROTO IX associated with normal ferrochelatase activity is paradoxical, unless the accumulation is that of PROTOGEN IX. Since PROTOGEN IX cannot be utilized by ferrochelatase to produce haem, it will accumulate in cells. During the extraction of porphyrins by organic solvents, PROTOGEN IX is readily oxidized to PROTO IX, which explains the results of the extraction experiments.

Hence, due to the auto-oxidation of PROTOGEN IX during extraction, both a PROTOGEN oxidase-deficient mutant and a ferrochelatase-deficient mutant would accumulate PROTO. However, ferrochelatase activity would be normal in a PROTOGEN oxidasedeficient mutant, but absent in a ferrochelatase-deficient mutant. On this basis, we consider that strain SASX38 is a PROTOGEN IX oxidase-deficient mutant (Fig. 1).

The PROTOGEN IX oxidase deficiency of the mutant also provides an explanation for the disappearance of PROTO in cultures incubated for $72 \mathrm{~h}$ (Table 2). In long-term cultures of the mutant, PROTOGEN IX is oxidized spontaneously to PROTO IX, which in turn is converted to haem by ferrochelatase. This haem is probably the source of the small amount of catalase activity found in $48 \mathrm{~h}$ cultures of the mutant.

According to the nomenclature proposed earlier (Săsărman \& Desrochers, 1976), the gene affected in strain SASX38 was designated hemG. The results of the mapping show that hem $G$ is located very close to $c h l B$, but analysis of classes of transductants did not allow us to determine the relative order of the hem $G$ and $c h l B$ genes. Thus, the real sequence in this segment could be metE chlB hemG rha or metE hemG chlB rha (Bachmann et al., 1976).

The location of the newly identified hem $G$ gene (see Fig. 3) confirms the well known dispersion of hem genes on the chromosome of E. coli K12 (Cox \& Charles, 1973; Powell et al., 1973; Săsărman et al., 1975, 1968a, 1968b). One exception to this rule could be the contiguity of the hemD (Chartrand et al., 1979) and popE (Powell et al., 1973) genes, as was suggested for the equivalent genes in S. typhimurium (Săsărman \& Desrochers, 1976). However, the published data (Cox \& Charles, 1973; Powell et al., 1973) do not allow an assessment of the contiguity of these two genes in E. coli $\mathrm{K} 12$, and further study would be necessary to clarify this point.

We are indebted to Michèle Paris and D. Charbonneau for their valuable contribution to the present work. This investigation was supported by grant MA4997 from the Medical Research Council of Canada to A.S. P.C. was the recipient of a studentship from the Medical Research Council of Canada.

\section{REFERENCES}

Bachmann, B. J., Low, K. B. \& Taylor, A. (1976). Recalibrated linkage map of Escherichia coli K-12. Bacteriological Reviews 40, 116-167.

Berek, I., Miczak, A., Kiss, I., Ivanovics, G. \& Durko, I. (1975). Genetic and biochemical analysis of haemin dependent mutant of Bacillus subtilis. Acta microbiologica Academiae scientiarum hungarica: 22, 157-167.

Chartrand, P., Tardif, D. \& Săsărman, A. (1979). Uroporphyrin and coproporphyrin I-accumulating mutant of Escherichia coli K12. Journal of General Microbiology 110, 61-66.

Cox, R. \& Charles, H. P. (1973). Porphyrinaccumulating mutants of Escherichia coli. Journal of Bacteriology 113, 122-132.

Dresel, E. I. B., Rimington, C. \& Tooth, B. E. (1956). Determination of urinary uroporphyrin by a direct extraction method. Scandinavian
Journal of Clinical and Laboratory Investigation 8, 73-78.

FALK, J. E. (1964). Porphyrins and Metallo-porphyrins. New York. American Elsevier.

Herbert, D. \& Pinsent, J. (1948). Crystalline bacterial catalase. Biochemical Journal 43, 193202.

JACKSON, A. H., Games, D. E., Couch, P., JACKson, J. R., BelCher, R. B. \& SMIth, S. G. (1974). Conversion of coproporphyrinogen III to protoporphyrin IX. Enzyme 17, 81-87.

JACOBS, N. J. \& JACOBS, J. M. (1975). Fumarate as alternate electron acceptor for the late steps of anaerobic heme synthesis in E. coli. Biochemical and Biophysical Research Communications 65, 435-441.

JACOBS, N. J. \& JACOBS, J. M. (1976). Nitrate, fumarate, and oxygen as electron acceptors for 
a late step in microbial heme synthesis. Biochimica et biophysica acta 449, 1-9.

KENNEDY, G. Y. (1956). A new method for the extraction of uroporphyrin I from mollusc shells. Scandinavian Journal of Clinical and Laboratory Investigation 8, 79-80.

Lascelles, J. (1964). Tetrapyrrole Biosynthesis and its Regulation. New York: W. A. Benjamin.

LASCELles, J. (1975). The regulation of heme and chlorophyll synthesis in bacteria. Annals of the New York Academy of Sciences 244, 334-347.

LAYNE, E. (1957). Spectrophotometric and turbidimetric methods for measuring proteins. Methods in Enzymology 3, 447-454.

LENNOX, E. S. (1955). Transduction of linked genetic characters of the host by bacteriophage P1. Virology 1, 190-206.

Perrin, D. D., Armarego, W. L. F. \& Perrin, D. P. (1966). Purification of Laboratory Chemicals. Oxford: Pergamon Press.

Porra, R. J. \& FALK, J. E. (1964). The enzymic conversion of coproporphyrinogen III into protoporphyrin IX. Biochemical Journal 90, 69-75.

Porra, R. J. \& Jones, O. T. G. (1963). Studies on ferrochelatase from a pig liver mitochondria extract. Biochemical Journal 87, 181-185.

Poulson, R. (1976). The enzymic conversion of protoporphyrinogen IX to protoporphyrin IX in mammalian mitochondria. Journal of Biological Chemistry 251, 3730-3733.

Poulson, R. \& Polglase, W. J. (1974). Site of glucose repression of heme biosynthesis. FEBS Letters 40, 258-260.

Poulson, R. \& Polglase, W. J. (1975). The enzymic conversion of protoporphyrinogen IX to protoporphyrin IX. Protoporphyrinogen oxidase activity in mitochondrial extracts of Saccharomyces cerevisiae. Journal of Biological Chemistry 250, 1269-1274.

Poulson, R., Whitlow, K. J. \& Polglase, W. J. (1976). Catabolite repression of protoporphyrin IX biosynthesis in E. coli K12. FEBS Letters 62 351-353.
Powell, K. A., Cox, R., McConville, M. \& Charles, H. P. (1973). Mutations affecting porphyrin biosynthesis in Escherichia coli. Enzyme 16, 65-73.

Rimington, C. (1960). Spectral-absorption coefficients of some porphyrins in the Soret-band region. Biochemical Journal 75, 620-623.

Sano, S. \& Granick, S. (1961). Mitochondrial coproporphyrinogen oxidase and protoporphyrin formation. Journal of Biological Chemistry 236, 1173-1180.

SĂsĂrman, A. \& DesRochers, M. (1976). Uroporphyrinogen III cosynthase-deficient mutant of S. typhimurium LT2. Journal of Bacteriology 128, 717-721.

Săsărman, A., Surdeanu, M. \& Horodniceanu, T. (1968a). Locus determining the synthesis of $\Delta$ aminolevulinic acid in Escherichia coli $\mathrm{K}-12$. Journal of Bacteriology 96, 570-572.

Săsărman, A., Surdeanu, M., Szegli, G., Horodniceanu, T., Greceanu, V. \& Dumitrescu, A. $(1968 b)$. Hemin-deficient mutants of Escherichia coli K-12. Journal of Bacteriology 96, 570-572.

Săsărman, A., Sanderson, K. E., Surdeanu, M. \& SONEA, S. (1970). Hemin-deficient mutants of Salmonella typhimurium. Journal of Bacteriology 102, 531-536.

Săsărman, A., Chartrand, P., Proschek, R., Desrochers, M., TARdif, D. \& Lapointe, C. (1975). Uroporphyrin-accumulating mutant of E. coli K-12. Journal of Bacteriology 124, 12051212.

TAIT, G. H. (1968). General aspects of haem synthesis. In Porphyrins and Related Compounds. Edited by T. W. Goodwin. New York: Academic Press.

TIEN, W. \& WhITE, D. C. (1968). Linear sequential arrangement of genes for the biosynthetic pathway of protoheme in Staphylococcus aureus. Proceedings of the National Academy of Sciences of the United States of America 61, 1392-1398.

WILSON, D. E. (1960). The effects of ultraviolet light and ionizing radiation on the transduction of E. coli by phage P1. Virology 11, 533-546. 